\title{
Kecukupan protein dan asupan zat besi pada anak sekolah dasar usia 8-12 tahun di Surakarta berdasar 7-day food diary
}

\section{Protein adequacy and iron intake of primary school children aged 8-12 yo in Surakarta based on 7-day food diary}

\author{
Dian Nazikha Khusna ${ }^{1}$, Setyaningrum Rahmawaty ${ }^{2 *}$, Avrianus Karo ${ }^{3}$, Ufairoh Maliha \\ Shofwah $^{4}$, Ari Murti Indriyati ${ }^{5}$, Niki Dwi Astuti ${ }^{6}$ \\ 1,2,3,4,5,6 Department of Nutrition Science, Faculty of Health Science, Universitas Muhammadiyah Surakarta, \\ Jl. A. Yani Tromol Pos 1 Pabelan Kartasura, Surakarta, Jawa Tengah, 57102., Indonesia \\ 1dian.nazikha17@gmail.com; ${ }^{2}$ sr130@ums.ac.id*; ${ }^{3}$ avrindkaro@gmail.com; ${ }^{4}$ ufairohmalihas@gmail.com; \\ 5nindymurti@gmail.com; ${ }^{5}$ nikii.sim36@gmail.com \\ *corresponding author
}

Tanggal Submisi: 3 Juni 2020, Tanggal Penerimaan: 14 Juli 2020

\begin{abstract}
Abstrak
Banyak bukti menunjukkan ada keterkaitan antara anemia defisiensi besi dan pengetahuan yang rendah pada anak sekolah. Anemia merupakan masalah kesehatan yang merugikan dan berdampak negatif terhadap pembangunan sosial-ekonomi di berbagai negara yang berpenghasilan rendah, menengah, maupun tinggi. Anemia dapat terjadi karena sejumlah penyebab, dengan kotributor paling signifikan adalah defisiensi besi. Kecukupan asupan protein menjadi hal utama yang perlu diperhatikan ketika menganalisis penyebab anemia defisiensi besi. Rancangan penelitian ini adalah cross-sectional untuk mengetahui hubungan kecukupan asupan protein dengan zat besi. Sebanyak 113 anak sekolah dasar usia 8-12 tahun di Surakarta berpartisipasi dalam penelitian yang dipilih berdasar multistage random sampling. Data asupan protein dan zat besi diperoleh dari catatan makan selama 7 hari (7-d food diary) secara berurutan yang dilakukan anak di rumah dengan pendampingan orang tua menggunakan bantuan buku model makanan bergambar (food images book). Kecukupan protein per hari diperoleh dengan membandingkan rerata asupan protein per hari dengan Angka Kecukupan Gizi (AKG) untuk orang Indonesia tahun 2013, sedangkan asupan zat besi per hari dinyatakan dalam $\mathrm{mg} /$ hari. Hasil penelitian menunjukkan $85 \%$ anak memiliki kecukupan protein tergolong kurang (asupan protein $<80 \% \mathrm{AKG}$ ) dan rerata asupan zat besi sebesar $3.3 \pm 1.5 \mathrm{mg} /$ hari. Hasil uji korelasi menggunakan Pearson Product Moment menunjukkan ada hubungan antara kecukupan asupan protein dan asupan zat besi pada anak sekolah dasar usia 8-12 tahun di Surakarta ( $p=0.001, \mathrm{RR}=4.043,95 \% \mathrm{CI}=3.109-5.258)$. Berdasarkan temuan ini, maka upaya meningkatkan konsumsi bahan makanan sumber protein perlu digalakkan guna mengoptimalkan asupan zat besi anak sekolah.
\end{abstract}

Kata kunci: anak sekolah dasar; asupan zat besi; kecukupan protein; 7d-food diary

\section{Abstract}

Iron deficiency anemia is a common nutritional problem among school-aged children in Indonesia. Desain of the study was cross-sectional to determine relationship between protein adequacy and iron intake among primary school children in Surakarta. One hundred thirthy three children aged 8-12 yo recruited using multistage random sampling were participated in this study. Protein and iron intake data were obtained from 7-day food diary filled out in a concecutively day by the children with their parents assistance using a food images book. Daily protein adequacy was compared to the nutritional adequacy rate 2013 (Angka 
Kecukupan Gizi/AKG in Bahasa) for Indonesian, while daily iron intake was presented in $m g /$ day. The results showed that $85 \%$ of the total children have low protein adequacy (protein intake $<80 \% \mathrm{AKG}$ ) and mean for iron intake was $3.3 \pm 1.5 \mathrm{mg} /$ day. Pearson Product Moment test showed that there was correlation between protein adequacy and iron intake among primary school children aged 8-12 yo in Surakarta $(p=0.001, \quad R R=4.043$, 95\%CI=3.109-5.258). Based on this data, efforts aimed to improve consumption of protein source foods need to be encouraged to optimize iron intake among school children.

Keywords: iron intake; primary school children; protein adequacy; $7 d$-food diary

\section{PENDAHULUAN}

Anemia merupakan masalah kesehatan yang merugikan dan berdampak negatif terhadap pembangunan sosial-ekonomi di berbagai negara yang berpenghasilan rendah, menengah, maupun tinggi. Anemia dapat terjadi karena sejumlah penyebab, dengan kotributor paling signifikan adalah defisiensi besi (Balarajan et al., 2011). Berdasarkan laporan Riskesdas tahun 2013 menunjukkan bahwa prevalensi anemia akibat kurangnya asupan zat besi pada anak usia 5-12 tahun di Indonesia sebanyak 29\% dari total populasi (Balitbang Kemenkes RI, 2013). Adapun angka kejadian anemia untuk Provinsi Jawa Tengah mencapai $51 \%$, yang melebihi ambang batas masalah anemia sebagai masalah kesehatan masyarakat yaitu $>20 \%$ (Dinas Kesehatan Jawa Tengah, 2018).

Zat besi terlibat dalam produksi sel darah merah di dalam tubuh. Jika tubuh kekurangan zat besi, maka jumlah sel darah merah akan berkurang, sehingga transportasi oksigen ke beberapa organ juga berkurang, kondisi ini disebut anemia defisiensi besi (Johnson-Wimbley \& Graham, 2011). Banyak bukti menunjukkan ada keterkaitan antara anemia defisiensi besi dan pengetahuan yang rendah pada anak sekolah (British Heart Foundation, 2011). Penelitian pada 113 anak sekolah dasar usia 9-13 tahun di Kabupaten Imogiri Kota Bantul, Yogyakarta menunjukkan 53\% (60 anak) yang menderita anemia memiliki rata-rata nilai matematika lebih rendah dibanding anak yang tidak menderita anemia (Puspaningtyas et al., 2012).

Kecukupan asupan protein menjadi hal utama yang perlu diperhatikan ketika menganalisis penyebab anemia defisiensi besi, sebab sumber zat besi dalam makanan lebih banyak ditemukan pada sumber protein hewani dan nabati (Abbaspour et al., 2014). Zat besi dalam bentuk protein hewani disebut besi heme, banyak ditemukan pada daging, unggas, dan ikan (Hurrell \& Egli, 2010). Bentuk protein nabati disebut besi non-heme, yaitu senyawa besi organik yang kompleks yang terdapat pada serealia, kacang-kacangan, sayuran, dan buah (Geissler \& Singh, 2011). Besi heme lebih mudah diserap hingga 10-20\% karena memiliki ketersediaan biologik (bioavailability) yang tinggi, dibanding besi non-heme yang mempunyai ketersediaan biologik sedang yang hanya bisa diserap 1-2\% (Anderson et al., 2005). Kehadiran zat gizi lain, seperti protein hewani, vitamin C, vitamin A, seng (Zn), dan asam folat dibutuhkan agar dapat meningkatkan penyerapan besi di dalam tubuh (Dietetian of Canada, 2014).

Protein memiliki peranan penting dalam metabolisme zat besi. Protein dalam bentuk ferritin atau transferin merupakan simpanan utama zat besi dalam darah, sedangkan beberapa peptida seperti iron regulatory protein (IRPs), hepcidin dan matriptase (Mt2) merupakan 
penentu utama regulasi zat besi (Waldvogel-Abramowski et al., 2014). Fungsi lain protein terhadap zat besi, yaitu sebagai alat transport dalam bentuk transferrin pada hemoglobin yang mengangkut oksigen dalam eritrosit. Adapun myoglobin berperan dalam pengangkutan ion besi dalam plasma darah yang selanjutnya dibawa ke dalam hati (Gropper et al., 2018). Oleh sebab itu, asupan protein yang inadekuat akan menggangu penyerapan dan distribusi zat besi di dalam tubuh yang dapat menyebabkan terjadinya ADB (Sudargo et al., 2015).

Kecukupan asupan protein seseorang penting untuk mengetahui kualitas makanan yang dikonsumsi, juga sebagai indikator menilai status asupan besi. Sebuah penelitian yang dilakukan di SMA N 2 Semarang terhadap 79 siswa perempuan, mengungkapkan bahwa sebanyak 62\% (49 siswa) yang memiliki asupan protein kategori diatas kecukupan berkorelasi positif dengan kadar hemoglobin $(\mathrm{Hb})(p=0.001, r=0.380)$, dimana semakin tinggi asupan protein maka kadar $\mathrm{Hb}$ semakin tinggi yang berarti kejadian anemia semakin rendah (Kirana, 2011). Untuk itu, pemilihan metode pengukuran asupan protein menjadi penting agar dapat memperoleh hasil yang lebih akurat.

Selama ini, pengukuran asupan protein yang biasa dilakukan berdasar recall makanan selama 24 jam ('Arasj, 2017). Metode ini memiliki kelemahan, diantaranya adalah tidak dapat menggambarkan kebiasaan makan apabila recall hanya dilakukan satu hari saja, bergantung pada memori responden (tidak direkomendasikan untuk usia $<12$ tahun), tergantung pada kapasitas pewawancara untuk menggambarkan bahan dan persiapan makanan, membutuhkan pewawancara terlatih baik untuk menemui secara langsung dan wawancara melalui telepon, kesulitan dalam memperkirakan "apa, bagaimana, dan seberapa banyak/kecil", serta "the flat slope syndrome" atau kecenderungan responden untuk menambah asupan yang sedikit dikonsumsi dan mengurangi makanan yang sering dikonsumsi (Castell et al., 2015).

Metode lain yang bisa digunakan untuk menilai asupan makan adalah food diary atau yang lebih dikenal dengan food record, atau dietary record. Metode ini memiliki kelebihan dalam mengumpulkan banyak informasi yang diperoleh dalam waktu berhari-hari, sehingga data konsumsi makanan yang didapat bisa lebih rinci, mudah diterapkan ke berbagai kelompok dengan berbagai kebiasaan makan dan dapat digunakan untuk memperkirakan ratarata asupan populasi tertentu (Ortega et al., 2015). Sebuah studi di Selandia Baru menunjukkan bahwa catatan harian makanan dapat digunakan sebagai alat bantu pengukuran zat gizi karena lebih akurat pada anak-anak (Davison et al., 2018). Di Indonesia sendiri, pernah dilakukan penelitian yang menggunakan aplikasi dengan metode food record pada 60 orang ibu yang memiliki anak sekolah dasar (8-12 tahun), hasil penelitian tersebut menerangkan adanya peningkatan skor asupan zat gizi anak dan skor pengetahuan ibu menerapkan konsumsi aneka ragam makanan gizi seimbang sebelum dan sesudah penggunaan aplikasi dengan metode food record (Okinarum et al., 2017). Penelitian ini bertujuan untuk mengetahui korelasi antara kecukupan asupan protein dan asupan zat besi berdasarkan 7-day food diary pada anak sekolah dasar usia 8-12 tahun di Surakarta.

\section{METODE PENELITIAN}

Jenis penelitian ini adalah observasional dengan pendekatan cross-sectional, yang dilaksanakan pada bulan Juli-September 2017. Responden adalah anak sekolah dasar usia 812 tahun di Surakarta yang diseleksi menggunakan multistage random sampling berdasar kecamatan, sekolah dan kelas. Sebanyak 246 anak yang terpilih secara random dan bersedia menjadi partisipan dalam penelitian ini menerima 7-day food diary, namun hanya 174 anak 
melengkapinya. Setelah melalui proses pengecekan, hanya 113 7-day food diary yang dapat dianalisis dalam penelitian ini (Diagram 1). Hasil tersebut sudah memenuhi sampel minimal yang dibutuhkan berdasarkan penentuan sampel dengan derajat ketepatan pendugaan besar sampel 10\% (0.1), sehingga didapatkan total minimal sampel sebanyak 96 sampel.

Penelitian ini telah mendapatkan persetujuan dari Komisi Etik Penelitian Kesehatan Fakultas Kedokteran, Universitas Muhammadiyah Surakarta Nomor: 713/B.1/KEPKFKUMS/VI/2017.

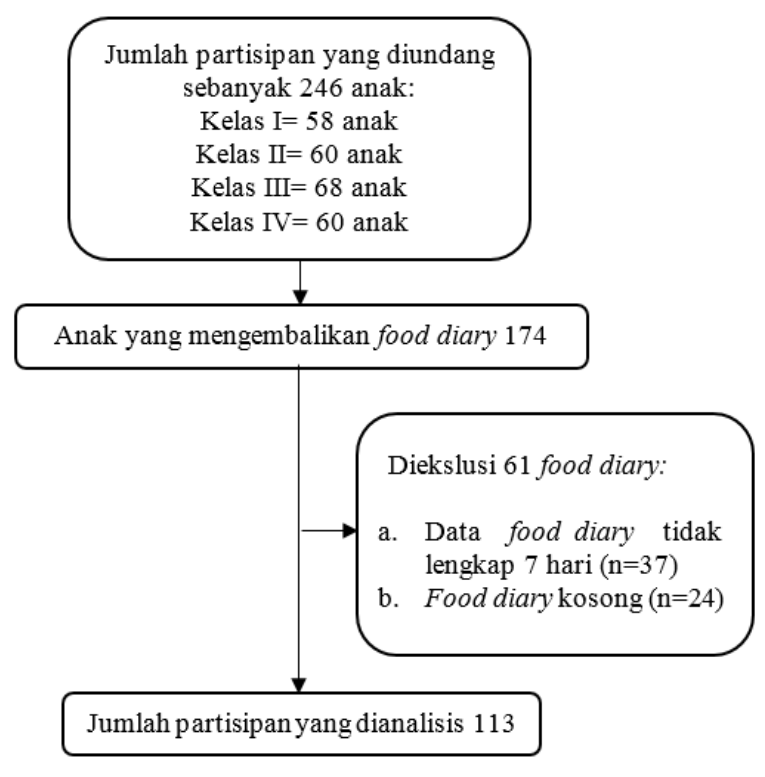

Diagram 1. Partisipan yang terlibat dalam penelitian

Setiap orang tua dari anak yang terseleksi sebagai sampel mendapat undangan untuk berpartisipasi dalam penelitian yang dikirim melalui anak saat di sekolah. Keikutsertaan anak sebagai responden dalam penelitian ini dibuktikan dengan tanda tangan anak dan orang tua pada lembar informed consent yang diberikan kepada peneliti saat di sekolah. Selanjutnya setiap anak yang telah menandatangani informed consent tersebut diminta mengisi food diary dengan mencatat semua jenis masakan/makanan yang dikonsumsi setiap hari selama 7 hari berturut-turut selama di rumah dengan didampingi orang tua masing-masing. Setiap anak juga menerima buku food model bergambar yang digunakan untuk membantu dalam pengisian food diary. Buku food model bergambar yang digunakan dalam penelitian ini dikembangkan secara spesifik untuk keperluan pengambilan data dalam penelitian ini dan telah diuji cobakan pada anak dan orang tua sebelum digunakan untuk pengambilan data.

Data makanan yang dikonsumsi setiap anak dalam 7-day food diary dikonversi ke dalam ukuran gram menggunakan acuan daftar bahan makanan penukar (BMP) yang diterbitkan oleh Direktorat Bina Gizi Masyarakat tahun 2003. Beberapa bahan makanan yang tidak ditemukan dalam daftar BMP seperti susu kental manis, mie instan, nugget ayam, dan biskuit, dianalisis kandungan zat gizinya dengan melihat komposisi yang tertera dalam setiap label atau kemasan. Adapun produk home industry seperti fish cake, crabstick, cilok, dan tempura dianalisis dengan terlebih dahulu mewawancarai penjual/pembuat makanan dan kemudian mengkonversikan dalam ukuran gram dari bahan-bahan makanan yang digunakan. Nutrisurvey for Windows 2007 digunakan untuk menganalisis kandungan zat gizi protein dan besi pada bahan makanan atau pun masakan. Rata-rata asupan protein setiap anak 
dibandingkan dengan Angka Kecukupan Gizi (AKG) Indonesia tahun 2013. Kategori kecukupan protein dibedakan menjadi 3 yaitu kurang apabila asupan $<80 \%$ AKG, baik apabila asupan antara 80-110\% AKG, dan lebih apabila asupan $>110 \%$ AKG. Kebutuhan protein dan zat besi menurut AKG untuk anak usia 7-9 tahun masing-masing sebesar 49 gram/hari dan $10 \mathrm{mg} /$ hari. Berdasarkan jenis kelamin (laki-laki dan perempuan), AKG untuk protein pada anak usia 10-12 tahun sebesar 56 gram/hari dan 60 gram/hari. AKG untuk zat besi pada anak usia 10-12 tahun (laki-laki dan perempuan) sebesar $13 \mathrm{mg} / \mathrm{hari}$ dan 20 $\mathrm{mg} /$ hari.

Analisis data menggunakan program SPSS (Statistical package for Sosial Science), Versi 20.0 for Windows. Berdasarkan uji kenormalan data menggunakan Kolmogorov Smirnov menunjukkan data terdistribusi normal. Uji Pearson Product Moment digunakan untuk mengetahui hubungan antara kecukupan asupan protein dan asupan zat besi responden.

\section{HASIL DAN PEMBAHASAN}

Penggunaan 7-day food diary dalam penelitian ini bukan hanya untuk mengetahui kecukupan zat gizi, akan tetapi juga dapat digunakan untuk melihat pola konsumsi responden karena dilakukan setiap hari secara berurutan selama 7 hari. Penelitian mengenai kecukupan asupan protein dan zat besi ini khususnya pada anak sekolah dasar di Indonesia masih terbatas, sehingga diharapkan bisa menjadi tambahan informasi guna penelitian selanjutnya.

Tabel 1. Analasis Karakteristik Anak Sekolah Dasar Usia 8-12 Tahun di Surakarta berdasar 7day-food diary

\begin{tabular}{lcc}
\hline & Frekuensi (n) & Persentase (\%) \\
\hline Jenis Kelamin & & \\
Laki-laki & 61 & 53.98 \\
Perempuan & 52 & 46.02 \\
Umur (tahun) & & \\
8 & 21 & 18.58 \\
9 & 27 & 23.89 \\
10 & 34 & 30.09 \\
11 & 22 & 19.47 \\
12 & 9 & 7.97 \\
Tingkat kecukupan protein & & \\
Kurang $(<80 \%$ AKG) & 96 & 84.96 \\
Baik $(80-110 \%$ AKG) & 16 & 14.16 \\
Lebih $(>110 \%$ AKG) & 1 & 0.88 \\
\hline
\end{tabular}

Karakteristik responden meliputi jenis kelamin, umur (tahun), dan tingkat kecukupan protein pada penelitian ini tersaji dalam Tabel 1. Berdasar sebaran jenis kelamin, tampak bahwa laki-laki lebih banyak (54\%) dibanding perempuan (46\%). Sekitar sepertiga bagian dari total responden tergolong usia 10 tahun (34 anak). Sebagian besar kecukupan protein responden tergolong kurang $(85 \%)$, hanya $14 \%$ anak tergolong baik. 
Tabel 2. Kecukupan Protein dan Asupan Zat Besi menurut Kelompok Umur dan Jenis Kelamin pada Anak Sekolah Dasar (8-12 tahun) di Surakarta

\begin{tabular}{|c|c|c|c|c|c|c|c|}
\hline & \multirow{2}{*}{$n$} & \multicolumn{2}{|c|}{$\begin{array}{c}\text { Kecukupan protein }{ }^{\mathrm{a}} \\
(\% \text { KKG//hari })\end{array}$} & \multirow[t]{2}{*}{$p$} & \multicolumn{2}{|c|}{ Asupan zat besi (mg/hari) } & \multirow{2}{*}{$p$} \\
\hline & & Mean \pm SD & Median & & Mean \pm SD & Median & \\
\hline \multicolumn{8}{|l|}{ Usia } \\
\hline 8 tahun & 21 & $68.1 \pm 13.4$ & 67.0 & $0.004^{\mathrm{b}}$ & $3.8 \pm 1.6$ & 3.0 & $0.338^{b}$ \\
\hline 9 tahun & 27 & $69.4 \pm 24.6$ & 68.0 & & $3.4 \pm 1.2$ & 3.3 & \\
\hline 10 tahun & 34 & $56.8 \pm 19.3$ & 56.0 & & $3.2 \pm 1.6$ & 2.6 & \\
\hline 11 tahun & 22 & $54.1 \pm 19.2$ & 54.0 & & $3.0 \pm 1.3$ & 3.0 & \\
\hline 12 tahun & 9 & $55.6 \pm 22.1$ & 55.0 & & $3.6 \pm 2.1$ & 3.2 & \\
\hline $\begin{array}{l}\text { Semua } \\
\text { umur } \\
\text { Jenis } \\
\text { kelamin }\end{array}$ & 113 & $61.3 \pm 20.7$ & 58.0 & & $3.3 \pm 1.5$ & 3.0 & \\
\hline Laki-laki & 61 & $61.9 \pm 20.4$ & 61.0 & $0.450^{\mathrm{c}}$ & $3.3 \pm 1.6$ & 3.0 & $0.721^{\mathrm{c}}$ \\
\hline Perempuan & 52 & $60.6 \pm 21.3$ & 57.5 & & $3.3 \pm 1.4$ & 3.1 & \\
\hline
\end{tabular}

${ }^{a}$ Persentase asupan protein per hari dibandingkan dengan AKG 2013 berdasarkan umur dan jenis kelamin

${ }^{\mathrm{b}}$ Uji Kruskall-Wallis untuk kategori usia; ${ }^{\mathrm{c}}$ uji Mann-Whitney untuk kategori jenis kelamin

Berdasar kecukupan protein dan asupan zat besi per kelompok umur dan jenis kelamin (Tabel 2), tampak bahwa kecukupan protein dan asupan zat besi lebih besar pada kelompok usia paling rendah yaitu 8 tahun dan menurun sejalan dengan pertambahan usia dimana secara statistik nilai Asymp.Sig $<0.005(p=0.004)$ yang artinya Ho ditolak, maka ada perbedaan yang nyata antara kecukupan protein dengan usia. Adapun berdasar jenis kelamin kecukupan protein kelompok laki-laki dan perempuan, tidak menunjukkan perbedaan yang signifikan.

Hasil uji statistik korelasi Pearson Product Moment menunjukkan ada hubungan yang bermakna antara kecukupan protein dan asupan zat besi pada anak sekolah dasar usia 8-12 tahun di Surakarta. Berdasar keeratan hubungan diperoleh angka 0.798 yang berarti korelasi antara kecukupan protein dan asupan zat besi adalah sangat kuat, dimana nilai $\mathrm{r}$ mendekati 1 . Analisis statistik dilanjutkan dengan regresi logistik dengan nilai relative risk $(\mathrm{RR})=4.043$ dan 95\%CI=3.109-5.258, yang menunjukkan bahwa anak sekolah usia dasar (8-12 tahun) di Surakarta dengan kecukupan asupan protein kurang memiliki risiko 4 kali lebih tinggi untuk memiliki asupan zat besi yang rendah. Jika dilihat dari jenis bahan makanan yang dikonsumsi responden, terlihat bahwa daging ayam memberi kontribusi asupan protein hewani tertinggi dari 20 jenis bahan makanan yang diidentifikasi sebagai bahan makanan sumber protein. Akan tetapi daging ayam tidak menyumbang asupan zat besi lebih besar dari hati ayam (Tabel 3). 
Tabel 3. Bahan makanan yang memberikan sumbangan protein dan zat besi pada anak sekolah dasar usia 8-12 tahun di Surakarta berdasar 7-day food diary

\begin{tabular}{|c|c|c|c|c|c|}
\hline \multirow{2}{*}{ Bahan Makanan } & \multicolumn{2}{|c|}{ Consumer } & \multirow{2}{*}{$\begin{array}{c}\text { Rerata } \\
\text { Konsumsi } \\
\text { (g/hari) }\end{array}$} & \multirow{2}{*}{$\begin{array}{c}\text { Rerata } \\
\text { Sumbangan } \\
\text { Protein (g/hari) }\end{array}$} & \multirow{2}{*}{$\begin{array}{c}\text { Rerata } \\
\text { Sumbangan Zat } \\
\text { Besi (mg/hari) }\end{array}$} \\
\hline & $\mathbf{n}$ & $\%$ & & & \\
\hline \multicolumn{6}{|l|}{ Protein Hewani } \\
\hline Daging ayam & 108 & 95.6 & 20.90 & 5.06 & 0.34 \\
\hline Telur ayam & 111 & 98.2 & 38.88 & 4.90 & 0.47 \\
\hline Daging kambing & 8 & 7.1 & 15.18 & 3.78 & 3.44 \\
\hline Hati ayam & 10 & 8.9 & 12.93 & 3.16 & 7.69 \\
\hline Ikan kakap & 21 & 18.6 & 14.76 & 2.44 & 0.45 \\
\hline Ikan lele & 51 & 45.1 & 16.10 & 2.38 & 0.35 \\
\hline Daging sapi & 34 & 30.1 & 9.28 & 2.31 & 0.16 \\
\hline Pempek & 15 & 13.3 & 17.73 & 2.24 & 0.43 \\
\hline Bakso daging sapi & 34 & 30.1 & 11.10 & 2.02 & 0.14 \\
\hline Susu kental manis & 79 & 69.9 & 22.01 & 1.72 & 0.05 \\
\hline Tempura & 34 & 30.1 & 8.59 & 1.56 & 0.07 \\
\hline Ikan bandeng & 54 & 47.8 & 10.19 & 1.51 & 0.13 \\
\hline Sosis ayam & 28 & 24.8 & 5.42 & 0.77 & 0.13 \\
\hline \multicolumn{6}{|l|}{ Protein Nabati } \\
\hline Nasi putih & 113 & 100 & 167.04 & 4.01 & 0.34 \\
\hline Cilok & 90 & 79.7 & 11.53 & 2.58 & 0.19 \\
\hline Tempe kedelai & 80 & 70.8 & 13.10 & 2.47 & 0.30 \\
\hline Roti coklat & 54 & 47.8 & 19.86 & 1.71 & 0.12 \\
\hline Mie basah & 48 & 42.5 & 17.68 & 0.85 & 0.09 \\
\hline Tahu & 80 & 70.8 & 9.89 & 0.82 & 0.54 \\
\hline Mie kering & 35 & 31 & 8.31 & 0.78 & 0.08 \\
\hline
\end{tabular}

Asupan protein nabati dengan rata-rata tertinggi kandungan proteinnya adalah nasi putih. Hal ini dikarenakan semua responden mengonsumsi nasi putih, diikuti tempe kedelai dan tahu, yang banyak dikonsumsi masing-masing 79.7\% dan $70.8 \%$ dari total responden (Tabel 3). Hasil penelitian ini menunjukkan bahwa terdapat hubungan yang signifikan antara kecukupan protein dengan asupan zat besi pada anak usia sekolah dasar. Artinya apabila kecukupan protein kurang maka dapat menghasilkan jumlah zat besi yang kecil, sehingga kecukupan zat besi pun menjadi kurang. Sebab peran penting protein adalah sebagai sumber zat besi, dimana protein hewani seperti daging mengandung banyak zat besi dan penyerapan dari sumber pangan tersebut di dalam tubuh sangat baik 20-30\% (Arisman, 2010).

Penelitian terhadap pola nutrisi yang dilakukan pada anak usia 5-12 tahun di Afrika Selatan menunjukkan bahwa, asupan gizi dari sumber protein nabati dan hewani yang kurang dapat berpengaruh pada status zat besi dan faktor penentu terjadinya anemia (Visser et al., 2019). Protein merupakan salah satu dari tiga makronutrien dalam makanan yang menyediakan kalori atau energi dalam tubuh dan berperan penting bagi tumbuh kembang anak. Penelitian di Desa Nyemoh, Kecamatan Bringin, Kabupaten Semarang, menujukkan adanya hubungan antara tingkat konsumsi protein dengan kejadian stunting, dimana dari 47 total responden $36.2 \%$ (17 balita) diketahui asupan proteinnya termasuk kurang dan mengalami stunting (Rahmawati, 2018). Sebagai alat pembawa (carrier) zat gizi, protein 
yang disebut transferrin dapat membawa zat gizi yang berbeda, misalnya mangan (Mn) dan besi $(\mathrm{Fe})$. Defisiensi protein akan mempengaruhi sintesis carrier, sehingga baik transportasi maupun penyerapan zat gizi dapat terganggu (Muchtadi, 2010).

Asupan protein dan asupan zat besi pada anak sekolah dasar dipengaruhi oleh beberapa faktor, diantaranya adalah kebiasaan jajan disekolah yang tidak baik. Menurut penelitian di SDN Babakan Sentral Kota Bandung, 93.6\% dari 110 siswa cenderung memilih jajanan yang banyak mengandung vetsin, selain itu faktor harga yang murah, dan aneka ragam warna yang menarik perhatian juga mendasari anak untuk membeli jajanan tanpa melihat kandungan gizinya (Iklima, 2017). Sehingga perlu adanya pengarahan agar anak dapat memilih jajanan yang sehat, karena tidak semua jajanan berbahaya, beberapa diantaranya memiliki kontribusi terhadap asupan zat gizi yang justru dibutuhkan anak. Seperti halnya studi penelitian yang dilakukan pada 24 anak di SD H. Isriati, Semarang, diketahui makanan jajanan memberikan kontribusi terhadap kecukupan energi $(10.81 \%)$ dan protein (12.82\%) (Sulistyanto \& Sulchan, 2010).

Hasil penilitian ini menunjukkan bahwa, sebagian besar siswa sekolah dasar di wilayah Surakarta yang menjadi responden (113 anak) diketahui mengkonsumsi sumber protein hewani yang berasal dari, telur ayam yaitu 111 anak (98.2\%), daging ayam yaitu 108 anak $(95.6 \%)$, dan susu kental manis yaitu 79 anak $(69.9 \%)$. Sedangkan bahan makanan sumber protein hewani yang paling sedikit dikonsumsi oleh responden adalah daging kambing (7.1\%). Sementara itu terdapat jenis makanan lain yang memiliki kontribusi cukup tinggi terhadap protein, yaitu nasi putih (4.01 g/hari) (Tabel 3). Hal ini menunjukkan bahwa kontribusi protein bukan hanya berasal dari kelompok pangan hewani maupun nabati saja, melainkan dari kelompok padi-padian seperti beras yang secara signifikan mempunyai sumbangan protein yang cukup besar. Tingginya proporsi protein yang berasal dari padipadian ini tidak lepas dari konsumsi beras oleh sebagian besar masyarakat Indonesia sebagai sumber makanan pokoknya (Kementrian Kesehatan RI, 2018).

Besaran konsumsi protein per kapita sebulan penduduk Indonesia masih didominasi oleh konsumsi yang berasal dari padi-padian (sebesar 10.94\%). Sementara itu, rata-rata konsumsi komoditas peternakan mengalami peningkatan di tahun 2018 yang berasal dari ikan serta telur dan susu, akan tetapi rata-rata konsumsi komoditas peternakan berupa daging dari tahun 2017 ke 2018 mengalami penurunan dari 9.09\% menjadi 5.94\% (Direktorat Jenderal Peternakan dan Kesehatan Hewan, 2018). Kekurangan konsumsi protein di Indonesia lebih banyak disebabkan oleh harga sumber protein hewani seperti ikan, daging, daging ayam, dan susu yang relatif mahal dan kurangnya edukasi dalam pentingnya mengkonsumsi makanan sumber protein hewani (Umaroh \& Vinantia, 2018).

Makanan jajanan seperti cilok juga cukup menyumbangkan protein yang tinggi sekitar $2.58 \mathrm{~g} /$ hari. Nilai ini justru lebih tinggi dari kelompok pangan nabati seperti tempe kedelai dan tahu yang merupakan sumber utama protein nabati dengan rata-rata kandungan protein sebanyak $2.47 \mathrm{~g} /$ hari dan $0.82 \mathrm{~g}$ /hari. Hal ini disebabkan jumlah konsumsi cilok lebih besar dibanding tempe kedelai dan tahu, sehingga kandungannya pun menjadi berbeda. Konsumsi makanan jajanan seperti cilok, pempek, roti coklat dan tempura dalam penelitian ini, menunjukkan kontribusi dari makanan jajanan cukup besar terhadap asupan protein, meskipun kandungan zat gizinya sedikit akan tetapi frekuensi konsumsi yang tinggi membuat makanan tersebut menyumbang asupan yang lebih besar (Tabel 3 ). 
Tingkat kecukupan protein pada anak sekolah dasar (8-12 tahun) di Kota Surakarta rata-rata dalam kategori kurang. Hal ini dapat terjadi karena sebagian besar responden masih jarang mengonsumsi makanan dengan kandungan protein yang tinggi seperti daging merah dan ikan serta kacang-kacangan dibanding jenis makanan seperti nasi yang kandungan proteinnya rendah (Tabel 3). Begitu pula asupan zat besi responden juga kurang terpenuhi, frekuensi konsumsi dan berat jenis bahan makanan dapat mempengaruhi kandungan zat gizi suatu bahan makanan. Sehingga pada Tabel 3 diketahui bahwa kandungan protein pada daging ayam tinggi, akan tetapi kandungan zat besinya tidak lebih besar dari hati ayam. Sama halnya dengan kandungan protein dari nasi putih yang paling tinggi diantara jenis makanan yang lain, justru kandungan zat besinya lebih kecil dari tahu yang kandungan proteinnya paling rendah (Tabel 3). Faktor ekonomi yang rendah dapat berpengaruh pada penyediaan makanan anak dari sumber protein baik hewani maupun nabati di rumah yang kurang variatif dan kurang sesuai dengan porsi URT (ukuran rumah tangga), sehingga mempengaruhi kecukupan asupan anak termasuk kecukupan zat besi didalam tubuh (Saputri et al., 2017).

\section{KETERBATASAN PENELITIAN}

Responden dalam penelitian merupakan anak sekolah dasar usia 8-12 tahun yang daya ingatnya terbatas, sehingga dapat terjadi underreport pada saat pengiisian food diary. Hal tersebut dapat mempengaruhi data asupan protein dan zat besi yang diperoleh.

\section{SIMPULAN}

Penelitian ini menunjukkan bahwa rerata kecukupan protein dan asupan zat besi pada anak sekolah dasar usia 8-12 tahun di Surakarta berada pada kategori kurang $(<80 \% \mathrm{AKG})$. Terdapat korelasi antara kecukupan protein dan asupan zat besi, dimana kecukupan protein yang kurang memiliki risiko 4 kali menyebabkan rendahnya asupan zat besi. Sehingga peningkatan asupan protein perlu ditingkatkan guna mengoptimalkan asupan zat besi pada anak sekolah.

\section{SARAN}

Perlu upaya untuk meningkatkan konsumsi pangan anak sekolah dasar di Surakarta yang tinggi asupan protein dan zat besi, karena berdasarkan hasil penelitian kedua asupan tersebut pada sebagian besar responden mengalami tingkat konsumsi dalam kategori kurang. Sumber protein seperti tahu, tempe kedelai, dan hati ayam perlu ditingkatkan agar asupan anak lebih variatif. Bahan makanan tersebut juga mudah dijumpai dan harganya pun terjangkau.

\section{UCAPAN TERIMAKASIH}

Penelitian ini merupakan bagian dari penelitian yang berjudul 'Survey Konsumsi Ikan pada Anak Sekolah Dasar di Surakarta' yang diketuai oleh S Rahmawaty dan mendapat dukungan pendanaan analisis data dari Lembaga Penelitian dan Pengabdian Universitas Muhammadiyah Surakarta melalui skema Doctorate Research Grant (No Kontrak: 132.25/A.3-III/LPPM/IV/2018). Ucapan terima kasih kami sampaikan kepada responden dan pihak-pihak yang terlibat dalam penelitian yang tidak dapat saya sebutkan satu persatu. Terima kasih juga disampaikan kepada Innani Karisma A, SGz.; Tri Suci K, SGz.; Farhanah E, SGz; dan Ola Puspita S, SGz yang telah membantu dalam pengambilan data. 


\section{DAFTAR PUSTAKA}

'Arasj, F. (2017). Survei Konsumsi Makanan. In Hardinsyah \& I. D. N. Supariasa (Eds.), Ilmu Gizi :Teori \& Aplikasi (1st ed., pp. 140-157). EGC.

Abbaspour, N., Hurrell, R., \& Kelishadi, R. (2014). Review on iron and its importance for human health. J Res Med Sci, 19(October), 164-174.

Anderson, G. J., Frazer, D. M., McKie, A. T., Vulpe, C. D., \& Smith, A. (2005). Mechanisms of haem and non-haem iron absorption: Lessons from inherited disorders of iron metabolism. BioMetals, 18(4), 339-348. https://doi.org/10.1007/s10534-005-3708-8

Arisman. (2010). Gizi dalam Daur Kehidupan (Suryani (ed.); 2nd ed.). EGC.

Balarajan, Y., Ramakrishnan, U., Özaltin, E., Shankar, A. H., \& Subramanian, S. V. (2011). Anaemia in low-income and middle-income countries. The Lancet, 378(9809), 21232135. https://doi.org/10.1016/S0140-6736(10)62304-5

Balitbang Kemenkes RI. (2013). RISET KESEHATAN DASAR 2013. Balitbang Kemenkes RI.

British Heart Foundation. (2011). Nutrition, health and schoolchildren Iron Deficiency Anaemia. 2. https://www.nutrition.org.uk/attachments/article/546/Iron deficiency anaemia and school children (2).pdf

Castell, G. S., Serra-majem, L., \& Ribas-barba, L. (2015). What and how much do we eat? 24-hour dietary recall method. Nutr Hops, 31, 46-48. https://doi.org/10.3305/nh.2015.31.sup3.8750

Davison, B. K., Quigg, R., \& Skidmore, P. M. L. (2018). Pilot testing a photo-based food diary in nine- to twelve- year old- children from Dunedin, New Zealand. Nutrients, 10(2). https://doi.org/10.3390/nu10020240

Dietetian of Canada. (2014). Food Sources of Iron. https://www.dietitians.ca/Downloads/Factsheets/Food-Sources-of-Iron.aspx

Dinas Kesehatan Jawa Tengah. (2018). Profil Kesehatan Provinsi Jawa Tengah Tahun 2018. Dinas Kesehatan Jawa Tengah.

Direktorat Jenderal Peternakan dan Kesehatan Hewan. (2018). Statistik Peternakan dan Kesehatan Hewan 2018/ Livestock and Animal Health Statistics 2018. Kementerian Peternakan RI. http://ditjenpkh.pertanian.go.id

Geissler, C., \& Singh, M. (2011). Iron, meat and health. Nutrients, 3(3), 283-316. https://doi.org/10.3390/nu3030283

Gropper, S. S., Smith, J. L., \& Carr, T. P. (2018). Advanced Nutrition and Human Metabolism (7th ed.). Cengage Learning.

Hurrell, R., \& Egli, I. (2010). Iron bioavailability and dietary reference values. American Journal of Clinical Nutrition, 91(5), 1461-1467. https://doi.org/10.3945/ajen.2010.28674F 
Iklima, N. (2017). Gambaran Pemilihan Makanan Jajanan Pada Anak Usia Sekolah Dasar. Keperawatan BSI, 5(1), 8-17. http://ejournal.bsi.ac.id/ejurnal/index.php/jk

Johnson-Wimbley, T. D., \& Graham, D. Y. (2011). Diagnosis and management of iron deficiency anemia in the 21st century. Therapeutic Advances in Gastroenterology, 4(3), 177-184. https://doi.org/10.1177/1756283X11398736

Kementrian Kesehatan RI. (2018). Konsumsi Makanan Penduduk Indonesia. Kemenkes RI. http://www.pusdatin.kemkes.go.id/resources/download/pusdatin/infodatin/infoDatinMakanan-2018.pdf

Kirana, D. P. (2011). Hubungan Asupan Zat Gizi dan Pola Menstruasi dengan Kejadian Anemia pada Remaja Putri di SMA N 2 Semarang. Universitas Diponegoro.

Muchtadi, D. (2010). Teknik Evaluasi Nilai Gizi Protein. Alfabeta.

Okinarum, G. Y., Afriandi, I., Gurnida, D. A., Herman, H., Garna, H., \& Djuwantono, T. (2017). Penggunaan Aplikasi Sayang ke Buah Hati (SEHATI) terhadap Asupan Zat Gizi Anak dan Pengetahuan Ibu Menerapkan Konsumsi Aneka Ragam Makanan Gizi Seimbang pada Anak Sekolah Dasar. Global Medical \& Health Communication (GMHC), 5(3), 219. https://doi.org/10.29313/gmhc.v5i3.2576

Ortega, R. M., Perez-Rodrigo, C., \& Lopez-Sobaler, A. M. (2015). Dietary assessment methods: dietary records. Nutricion Hospitalaria, 31, 38-45. https://doi.org/10.3305/nh.2015.31.sup3.8749

Puspaningtyas, D. E., Sudargo, T., \& Syamsiatun, N. H. (2012). Hubungan Status Anemia, Praktik Pemberian Makan, Praktik Perawatan Kesehatan, dan Stimulasi Kognitif dengan Fungsi Kognitif Anak Sekolah Dasar. Gizi Indonesia, 35(2), 109-119.

Rahmawati, H. (2018). Hubungan tingkat konsumsi energi dan protein anak balita dan perilaku keluarga sadar gizi (kadarzi) dengan kejadian. Universitas Muhamadiyah Surakarta.

Saputri, R., Lestari, L. A., \& Susilo, J. (2017). Pola konsumsi pangan dan tingkat ketahanan pangan rumah tangga di Kabupaten Kampar Provinsi Riau. Jurnal Gizi Klinik Indonesia, 12(3), 123. https://doi.org/10.22146/ijcn.23110

Sudargo, T., Kusmayanti, N. A., \& Hidayati, N. L. (2015). Defisiensi Yodium, Zat Besi, dan Kecerdasan (M. Hakimi (ed.)). Gadjah University Press.

Sulistyanto, J., \& Sulchan, M. (2010). Kontribusi Makanan Jajanan terhadap Tingkat Kecukupan Energi dan Protein serta Status Gizi dalam Kaitannya dengan Prestasi Belajar. Media Medika Muda, 4, 31-38.

Umaroh, R., \& Vinantia, A. (2018). Analisis Konsumsi Protein Hewani pada Rumah Tangga Indonesia. Jurnal Ekonomi Dan Pembangunan Indonesia, 1, 22-32. https://doi.org/10.21002/jepi.v0i0.869

Visser, M., Van Zyl, T., Hanekom, S. M., Baumgartner, J., van der Hoeven, M., TaljaardKrugell, C., Smuts, C. M., \& Faber, M. (2019). Nutrient patterns and their relation to 
anemia and iron status in 5- to 12-y-old children in South Africa. Nutrition, 62, 194200. https://doi.org/10.1016/j.nut.2019.01.016

Waldvogel-Abramowski, S., Waeber, G., Gassner, C., Buser, A., Frey, B. M., Favrat, B., \& Tissot, J. D. (2014). Physiology of iron metabolism. Transfusion Medicine and Hemotherapy, 41(3), 213-221. https://doi.org/10.1159/000362888 